\title{
An Examination Of Internships And Job Opportunities
}

\author{
John T. Rigsby, Mississippi State University, USA \\ Noel Addy, Mississippi State University, USA \\ Clyde Herring, Dean, College of Business, Carson-Newman College, USA \\ Donna Polledo, Doctoral Student, Mississippi State University, USA
}

\begin{abstract}
This paper reports the results of an empirical study examining the relationship between participation in an accounting internship and increased job opportunities. Most prior studies have examined the benefits of internship programs while in school or the benefits of internships on professional learning, socialization, and personal characteristics in preparing students for entry into the profession. There has been a paucity of empirical studies examining the relationship between internships and job opportunities, which is a primary reason why students enter internship programs, schools establish them, and employers hire interns. We surveyed professional employees below the manager level among three Big 4 firms and a large regional CPA firm, and found that the effect of internship experience on job opportunities depends upon the circumstances. The results indicate that employing firms highly value internship experience and that internship experience is useful for students in getting job opportunities whether or not they stay with the internship firm.
\end{abstract}

Keywords: Internships; Job Opportunities

\section{INTRODUCTION}

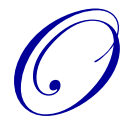

ver $94 \%$ of colleges of business offer some type of internship to their students (Weible, 2010), and the rate of utilization has increased significantly for accounting majors, from 39\% in 1995 to 60 percent in 2006 (Nelson, Vendrzyk, Quirin \& Allen, 2002; Nelson, Vendrzyk, Quirin \& Kovar, 2008). Internships are expected to benefit students in many ways. One of the most important expected outcomes and benefits of an internship experience for students and schools is improvement in the opportunity for permanent job offers (Beard, 1998; Knouse, Tanner \& Harris, 1999). Few studies, however, have examined the benefits of an internship on the job (e.g., Henry, 1979; Siegel \& Rigsby, 1988; Gault, Redington \& Schlager, 2000) and fewer still whether the internship experience results in increased job opportunities for students.

Most studies, instead, have examined the usefulness of internship experience for students when they return to the classroom or the usefulness of internship experience in helping some aspect of students' development preparing them to enter the profession. Among these studies, a number have evaluated the benefit of internship experience to grade point average (GPA) when students return to the class (Koehler, 1974; Knechel \& Snowball, 1987; Giacomino, 1990; English \& Koeppen, 1993; Myring, Bloom, \& Shortridge, 2005). Other studies have examined the usefulness of an internship experience for career exploration and reality testing, socialization into the norms of the workplace and its technical competencies, improvements in knowledge acquisition and insight in preparing students for entry into the profession, and emotional sharing (Kane, Healy \& Henson, 1992; Eyler, 1992; Maletta, Anderson \& Angelini, 1999; Martin \& Wilkerson, 2006; Beck \& Halim, 2008; Liu, Xu \& Weitz, 2011; Green, B., Graybeal, P. \& Madison, R., 2011). For example, Martin and Wilkerson (2006, p. 130) examined the attitudes of students and found that an internship experience strengthens "the professional and business context of accounting students," facilitating "more active, independent learning and problem-solving by students," and is related to career enhancement more than academic performance. 
In this study we examine a set of research questions evaluating the number of job opportunities available to students who complete internships. The question is important because of the increase in internships in accounting and business. While most interns hope they will be offered a full-time permanent position, there normally are a number of interns who either are not extended a job offer at the end of the internship or who choose not to accept the job offer. The opportunity of permanent job offers to participants in an internship program represents a substantive and important expected benefit among students. Students are the "most important beneficiary of the internship outcomes" (Moghaddam, 2011, p. 287). Schmutte (1986, p. 228) suggests, "the ultimate test of any internship program is the extent to which participating students are benefited" and one of the most important results should be better job opportunities (Beard, 1998; Knouse, et al., 1999). Beck and Hamil (2008, p. 152), for example, concerning the benefits of internships state, "On more pragmatic considerations, students who have undertaken internships tend to receive more job offers before graduation than their counterparts who have no internship experience." Thus, positive job opportunities are generally expected from an internship experience. Yet there are no empirical studies that have examined this question. The results are expected to be of significant interest to the universities offering internship programs, students considering an internship program, and firms participating in internship programs.

We find that the usefulness of the internship experience to job opportunities varies among interns. It is negative among those interns accepting a permanent job offer and positive for those interns either rejecting the permanent job offer or who were not extended a job offer. Our results indicate that the internship experience is highly valued by potential employers and useful to interns whether they stay with the internship firm or seek a job with another firm.

\section{Hypotheses Development and Research Method}

This section of the paper describes hypotheses development and the research method.

\section{Internships and number of job offers}

Academic accounting programs have worked with firms to provide student internships for many years. Administrators and faculty have promoted such programs by asserting that internships improve a student's ability to get a job. Yet, students who do not pursue an internship still obtain employment upon graduation. So, why do universities pursue the path of providing internship opportunities for students? As discussed earlier, reasons may include providing students with practical experience to apply in academic classes as well as the development of knowledge, skills, and emotional expressions useful in the profession. However, job placement is often the primary reason given by administrators, faculty, and parents for utilizing an internship (Beard, 1998; Knouse et al., 1999).

We examined the relationship between the internship experience and the number of job offers received. ${ }^{l}$ Internships are part of an intensive job search behavior. Varying results have been found regarding the relationship of the internship experience with the number of job offers. Horowitz (1996), among journalism majors, did not find that having an internship increased the number of job offers, while Knouse et al. (1999), among business majors, found that internship experience increased the likelihood of having a job at graduation. ${ }^{2}$ We hypothesized a series of outcomes as a result of the internship experience that we believe will differentiate among the number of job offers students receive. Our expectation is that the internship experience depending upon the circumstances can have a positive or a negative effect on the number of job offers.

\footnotetext{
${ }^{1}$ We also considered starting salaries, since some studies have found a positive relationship between salaries and internship experience (e.g., Horowitz, 1996; Gault et al., 2000). Because our respondents are from large accounting firms not much variation in salaries was expected or found. On a demographic note, a two-sample t-test with unequal variance was run and the average salaries for men was $\$ 42,870$ (with a sample size of 41 and standard deviation of 4.09 ) and for women was $\$ 42,380$ (with a sample size of 40 and standard deviation of 5.00). The resulting p-value of 0.63 indicates the lack of a significant difference between male and female starting salaries. Sample size was reduced by one for the women respondents because one of them did not provide starting salary information.

${ }^{2}$ Other studies have shown that students with internships usually need a shorter time to first position (Henry, 1979; Gault, et al., 2000).
} 
For those students who intern and receive an offer of employment from the internship firm, most of them generally do not re-enter the job market. As a result, these students are expected to have fewer job offers than those students who do not intern. The following hypothesis will be tested for this result:

$\mathbf{H}_{1}$ : $\quad$ Participants who experience internships have fewer job offers than those who do not experience internships.

Students with internships do not always take a permanent position with the internship firm. Reasons for this trend include the following: (1) the firm does not extend an offer either because there are insufficient job openings or the intern is not a desirable fit for its needs, or (2) the firm extends an offer, but the intern rejects it because he or she does not perceive a desirable fit with the firm. In either case, the interns pursue other job alternatives. If potential employers value internships, then positive net benefits should be found for students completing an internship (Beck \& Hamil, 2008). Students in both (1) and (2) above should have more job offers than students who had not experienced an internship. As a result, the following hypotheses will be tested:

$\mathbf{H}_{2}$ : $\quad$ Participants with internships who did not receive offers from the internship firms have more job offers than those who did not intern.

$\mathbf{H}_{3}$ : $\quad$ Participants with internships who received and declined offers from the internship firms have more job offers than those who did not intern.

We also include two possible control factors that could explain the number of job offers, independently of the internship experience: (1) membership in Beta Gamma Sigma ${ }^{3}$ and (2) undergraduate grade point average (GPA). Undergraduate GPA and Beta Gamma Sigma provide measures of the students that could supply alternative, independent explanations for an increase in job offers. GPA was selected based on discussions with Human Resource representatives from Big 4 accounting firms about important recruiting criteria. While they are related, Beta Gamma Sigma membership could potentially provide additional information beyond grade point average since members are required to be in the top 10 percent of their undergraduate senior class or the top 20 percent of their graduate class. Beta Gamma Sigma membership may also provide additional information about the quality of the business programs students are graduating from because of the selection process used in determining BGS chapters.

The following hypotheses test these factors.

$\mathbf{H}_{4}$ : $\quad$ Participants who are members of Beta Gamma Sigma will receive more job offers than those who are not members of Beta Gamma Sigma.

$\mathbf{H}_{5}$ : $\quad$ Participants with higher undergraduate GPAs will receive more job offers than those with lower undergraduate GPAs.

\section{Data collection and research method}

We surveyed professional accountants in the southeast region of the U.S. below the level of manager in the offices of three of the Big 4 accounting firms and an office of a large regional accounting firm. ${ }^{4}$ Generically these positions would be called staff accountants and senior accountants, though the titles and levels within them vary by firm. Data were gathered in 2005 by attending staff meetings of the firms in two different cities. At the beginning of

\footnotetext{
${ }^{3}$ We also considered including Beta Alpha Psi (BAP), the accounting honor society, but did not include it because most accounting majors who qualify join BAP, thus a discriminating effect was not expected (nor was it found).

${ }^{4}$ Large CPA firm was defined as being in the top 60 CPA firms in the US and top 10 in the region using revenue as the criterion (excluding the Big 4 and national firms), and being Public Companies Accounting Oversight Board (PCAOB) qualified. Being PCAOB qualified indicates that the firm competes with the Big 4 firms and others for audit clients among publicly traded companies and is able to meet the PCAOB's quality control standards.
} 
the meetings, all professional staff and seniors filled out the survey instrument shown in the Appendix. Average time of completion was 15 to 20 minutes. Information was gathered on: (1) membership in student organizations, (2) undergraduate GPA, (3) internship experience, and (4) job offers. A total of 96 surveys were completed, and after reducing for missing responses we had 82 usable instruments.

We used probit regression in the analysis of the data to test hypotheses 1 through 5 because we are estimating the probability that a respondent will fall into one of two categories. ${ }^{5}$ To test whether internships can result in multiple job offers, we estimated the following equation:

Prob(Multiple Job Offers) = f(Internship, No Offer, Rejected Offer,

Beta Gamma Sigma, Undergraduate GPA)

The equation estimates the probability that a student who returns to the job market is more likely to have more than one job offer compared to a student who never had an internship. The three independent variables of interest are whether the student had an internship experience (Internship) and whether they returned to the job market, either with no offer from the internship (No Offer) or after rejecting an offer from the internship (Rejected Offer). Additional variables included to act as potential controls are membership in Beta Gamma Sigma (Beta Gamma Sigma), and a self-reported measure of undergraduate GPA (Undergraduate GPA).

\section{Analysis of Results}

The demographics of the internees are shown in Table 1, with the results of the two sets of hypotheses presented in the remainder of this section. Table 1 indicates that the split between male and female was 50 percent, with 72 percent of the respondents being 25 years of age or less. The majority of the internees were Caucasian or White ( 82 percent), with some Hispanic (6 percent), Asian or Pacific (5\%), African American (4 percent), and Native American (4 percent).

Table 1

Demographics Among Internees

\begin{tabular}{lcc}
\hline Panel A: Gender & N & decimal \\
\hline Male & 41 & 0.50 \\
Female & 41 & 0.50 \\
\hline Total & 82 & 1.00 \\
Panel B: Age & $\mathbf{N}$ & decimal \\
\hline 22 & 6 & 0.07 \\
23 & 14 & 0.17 \\
24 & 22 & 0.27 \\
25 & 17 & 0.21 \\
26 & 11 & 0.13 \\
27 & 5 & 0.06 \\
$>27$ & 6 & 0.07 \\
No response & 1 & 0.01 \\
\hline Total & 82 & 1.00 \\
Panel C: Ethnic Background & $\mathbf{N}$ & decimal \\
Asian American or Pacific Islander & 4 & 0.05 \\
African American or Black & 3 & 0.04 \\
Caucasian or White & 67 & 0.82 \\
Native American or Indian & 3 & 0.04 \\
Mexican American or Hispanic & 5 & .06 \\
\hline Total & 82 & 1.00
\end{tabular}

\footnotetext{
${ }^{5}$ When dependent variables are explained by a set of independent variables, Ordinary Least Squares (OLS) regression is frequently used to estimate the effect of the independent variables. However, when the dependent variable is in categories, say zero or one, OLS regression can produce predictions that cannot exist, e.g., negative values when only zero or one can exist (Kennedy, 2003, pp. 259-280). Probit regression overcomes this limitation.
} 


\section{Internships and number of job offers}

The number of job offers among the eighty-two respondents is shown in Table $2{ }^{6}$ Twenty-nine respondents applied for and received an internship and accepted a permanent job offer. Among these respondents, sixteen had a single job offer and thirteen had more than one offer. Seven respondents applied for and received an internship, but rejected a permanent job offer. Among these respondents, one received only one job offer, and six received more than one job offer. Fourteen respondents applied for and participated in an internship experience, but received no permanent job offers from the firms. Among these respondents, one received only one job offer and thirteen received more than one job offer. Finally, thirty-two respondents did not apply for nor receive an internship. ${ }^{7}$ Among them, seven received only one job offer and twenty-five received more than one job offers.

Table 2

Frequency of offers

\begin{tabular}{lccc}
\hline Variable & n & One offer & More than one offer \\
\hline Accepted the offer after the internship & 29 & 16 & 13 \\
Rejected the offer from the internship & 7 & 1 & 6 \\
No offer from the internship & 14 & 1 & 13 \\
No internship & 32 & 7 & 25 \\
\hline Total & 82 & 25 & 57 \\
\hline
\end{tabular}

1. Student had an internship is coded one if the student did have an internship, zero otherwise.

2. Rejected an offer from the internship is one if the student rejected the offer made during the internship, zero otherwise.

3. No offer from the internship is coded one if the student did not have an offer at the end of the internship, zero otherwise.

Table 3 reports the probit regression of number of job offers where the dependent variable is between one offer and more than one offer. ${ }^{8,9}$ Our first hypothesis examines whether students with internships received fewer offers than those without internships. Our expectation was a negative relationship since most students normally receive an offer from the internship firm and accept it, and so would not participate in additional job interviews. Our results are significant and negative (i.e., - .83 coefficient and a t-value of -2.28), indicating support for $\mathrm{H}_{1}$ that students with internships have fewer job offers.

\footnotetext{
${ }^{6}$ To evaluate the representativeness of the numbers in Table 2, we compared the acceptance rate of interns in the sample with the percentage of the 2005 entry-level hires of the Big 4 firms who were former interns. Twenty-nine of the participants in the study accepted a job offer after the internship among the fifty participants with internship experience for a .58 acceptance rate. Three of the Big 4 firms are listed in the top 50 best places to launch a career (Businesssweek, 2006) with the percentage of entry-level hires who were former interns ranging from .36, .60 and .88, and averaging .61, so the acceptance/rejection rate appears appropriate for the year 2005 .

${ }^{7}$ In our survey, none of the respondents stated that they applied for internships and did not receive them. This is not a random sample of students, but rather a set of successful students employed by large accounting firms. Students who applied for internships and did not receive them may not be present in the sample or may not be willing to admit failure in applying for an internship.

${ }^{8}$ Other definitions of dependent variables were examined and this was the most significant.

${ }^{9}$ We found no obvious sign of model misspecification in Table 3. Coefficients tend to remain significant when other variables are individually dropped, and the coefficients do not tend to change sign when other variables are individually dropped.
} 
Table 3

Probit regression of number of offers on independent variables

\begin{tabular}{ll}
\hline Variable & -0.62 \\
\hline $\begin{array}{l}\text { Intercept } \\
\text { (t-value) }\end{array}$ & $(-0.64)$ \\
Internship & -0.83 \\
Student had an internship & $*(-2.28)$ \\
No offer from the internship & 1.66 \\
& $*(2.81)$ \\
Rejected an offer from the internship & 1.40 \\
& $*(2.10)$ \\
Control variables & -0.30 \\
Beta Gamma Sigma & $(-.64)$ \\
Undergrad. GPA & 0.40 \\
\hline Model log likelihood & $(1.50)$ \\
\hline Pseudo R & -42.06 \\
\hline
\end{tabular}

* Indicates significance at the $.05 \mathrm{p}$-value level.

\#The log likelihood ratio for the intercept alone is -50.43 .

1. The dependent variable is whether the student had more than one job offer, which was coded one, or just one job offer, coded zero.

2. Student had an internship is coded one if the student had an internship, zero otherwise.

3. No offer from the internship is coded one if the student did not have an offer at the end of the internship, zero otherwise.

4. Rejected an offer from the internship is coded one if the student rejected the offer made during the internship, zero otherwise.

5. Beta Gamma Sigma is whether the student jointed Beta Gamma Sigma, zero otherwise.

6. Undergraduate GPA is self-reported in categories coded: 1 for $<2.80 ; 2$ for $2.80-3.19 ; 3$ for 3.20-3.59; and 4 for 3.60-4.00. For probit regression, the Likert categories are recoded into two levels: zero for 3.19 or less; 1 for 3.2 and higher.

Our second hypothesis examined whether students who interned but did not receive an offer from the internship firm received more job offers than students who had not interned. We hypothesize that the internship experience will add value to the student's record providing him or her with more job offers than a student who did not have an internship. Our results are significant and positive (i.e., 1.66 with a t-statistic of 2.81), indicating support for $\mathrm{H}_{2}$. We conclude that students who intern, but do not receive offers from the internship firms, will receive more job offers than students who do not intern.

Our third hypothesis examined whether students who interned and received a job offer but declined it had more job offers than students who did not intern. Again, we are expecting the internship experience to provide added value to the student, resulting in more job offers. Our results are again significant and positive (i.e., 1.40 with a tstatistics of 2.10), indicating support for $\mathrm{H}_{3}$. Therefore, we conclude that students who decline offers from internship firms will have more job offers than students who do not intern.

We also examined two control variables in hypotheses four and five. These hypotheses examined the relationship between Beta Gamma Sigma membership and undergraduate grade point average with the number of job offers. We did not find a significant relationship for either variable, eliminating them as alternative explanations of the results of the study. 


\section{CONCLUSIONS, LIMITATIONS, FUTURE RESEARCH}

\section{Conclusions}

With relatively few internship studies, it is not surprising that some basic and important questions regarding career outcomes have not been addressed. We investigated whether students with internship experience benefitted with an increased number of job opportunities. Job opportunities are one of the most significant expected benefits from participating in an internship experience.

We found the impact of the internship experience to be positive in some situations and negative in others. Those students who experienced an internship and accepted the related job offer received fewer job offers than those students who did not participate in an internship experience. Conversely, students who did not receive a job offer from the internship firm or who rejected a job offer from the internship firm received more job offers than students without an internship experience, indicating that employing firms value internship experiences placing students with internships in a better position than non-interns in getting job opportunities.

Both the positive and the negative findings of the study indicate that employers and students recognize the value of internship experience. Potential explanations of the usefulness of internships to employing firms are multiple and likely variable depending upon circumstances. Two of the main explanations of benefits resulting from the internship experience are (1) a better matching and selection process from both the interns and potential employers perspectives (Siegel \& Rigsby, 1988; Gault, Redington, \& Schlager, 2000), (2) and better development of interns' professional skills, knowledge, socialization and other abilities during the internship (Pasewark, Strawser, \& Wilkerson, 1989; English \& Koeppen, 1993; Maletta et al, 1999; Gault et al., 2000). Of these two explanations, the one that perhaps is most dominant in explaining the negative relationship for students appears to be the better matching process, with the developmental aspects playing an important role. The negative relationship reflects benefits to the interns. Being satisfied with their development and socialization process as it fits within the matching process with the internship firm, students do not change their commitment to the firm and do not seek further job offers. For internship firms the matching process is clearly dominant. The firms benefit by getting to evaluate how interns perform in a job environment before making the final job offer thereby increasing the likelihood of selecting students that best fit the firm's needs and have the greatest potential to make contributions to the firm's future.

In explaining the two positive relationships for job opportunities, the enhanced development explanations appear to come into play more importantly, particularly for students, who have been found to rate skill development significantly higher than internship providers (Swanson \& Tomkovick, 2012). The matching explanation remains the dominant component for employers. Only outstanding students are normally selected for internships and there has been some development of their knowledge, socialization, abilities and emotional expression through the internship experience with regard to the profession. The job interview is a matching process between the needs of the firm and the characteristics and development potential of students and firms will make their evaluations in determining job offers within the pool of students that are being considered. Our findings indicate that internship experience (and the characteristics of students associated with internships) is useful for students in getting job offers whether a job offer is received from the internship firm or not and is a desirable component of an educational curriculum for entry into the accounting profession.

\section{Limitations}

The results of this study occurred within the parameters of the internship and recruiting requirements of the Big 4 accounting firms and the large regional CPA firm in the cities where the data were collected and the ethnic makeup of the internees. The results may not hold for accounting job offers in industry or financial services or for small regional or local CPA firms. A significant change in the ethnic make-up of the sample group could also affect the results of the study. 


\section{Future research}

More investigations into the nature of internships are needed. Our study provides several interesting insights into the relationship between participation in accounting internships and first time job opportunities. An interesting extension would be to apply the analysis to non-Big 4 accounting firms as well as smaller industrial and financial firms. While firms of all sizes use internships, smaller firms are not expected to emphasize internships to the same extent as larger accounting and industrial firms where in recent years internships have become in many cases almost a prerequisite to employment. Another interesting study would be a comparative analysis between larger versus smaller accounting firms and industrial firms. Significant differences are likely to develop in the way they use internships. Larger firms have been better able to leverage their internship experience with students and increase its essentialness for getting a job offer from them.

\section{AUTHOR INFORMATION}

John T. Rigsby, Graduated from the University of Memphis with a doctorate in accountancy. Assistant Professor at Southern Illinois University in Carbondale for several years before coming to Mississippi State University where he has been for 24 years. Published over 30 articles over the years including Journal of Accounting and Organizational Change, Journal of Applied Business Research, Managerial Auditing Journal, Advances in Accounting, Accounting, Auditing and Accountability Journal, The British Accounting Review, and Behavioral Research in Accounting. Active in two sections of the American Accounting Association: Public Interest section (Southeastern Representative); Accounting, Behavioral and Organizations section (Working Paper Editor). Treasurer for the Academy of Accounting Historians for three years. Wife (Debra) and two children, JT and Nicole. E-mail: jrigsby@cobilan.msstate.edu (Corresponding author)

Noel Addy, Graduated from the University of Florida with a doctorate in accountancy. Assistant Professor at Texas A \& M University for several years before coming to Mississippi State University where he has been for about 22 years. Published numerous articles in academic journals over the years. Active in several organizations: Beta Alpha Psi Accounting Honorary Society (in charge of the MSU chapter for several years, currently on the National Board of Directors); Phi Kappa Phi National Honor Society (currently Treasurer for MSU chapter). Wife (Shelley) and two children. E-mail: naddy@cobilan.msstate.edu

Clyde Herring, Supervising Senior-Tax for four years with Peat Marwick, Mitchell \& Co. after graduating from Mississippi State University with a MPA degree. Graduated from the University of Alabama with a doctorate in accountancy. Assistant Professor and then Associate Professor at Mississippi State University for 23 years. He was Interrim Director of the Adkerson School of Accountancy twice. He was Beta Alpha Psi advisor at the School for many years, then became the Southeast Regional Director of BAP. Active with the Mississippi Society of CPAs becoming President of the Northeast Chapter, moving on to the Board of Directors of the MSCPA for several years and then being elected President of the organization for a year. Clyde became Dean of the School of Business at Carson-Newman College in Tennessee and now serves as MBA Director. He has a wife (Tammye) and two children, Christopher and Jordan. E-mail: ceherring@cn.edu

Donna Polledo, Received undergrad degree in accounting from University of Louisiana at Monroe and an MBA with an MIS emphasis from the University of New Orleans. Passed CPA exam and worked for Peat, Marwick, Mitchell \& Co. (KPMG) for a year before moving on to several positions with various companies as Senior Auditor, Manager-Internal Audit, Manager-General Accounting, and Manager-Asset Accounting. She then became a Management Consultant and worked for several firms (one of which was PriceWaterhouseCoopers) before entering the doctoral program at MSU. She taught at Southeastern Louisiana State University for several years. She has completed course work and the comprehensive examination and is working on the dissertation. E-mail: $\underline{\mathrm{dsp} 43 @, \text { msstate.edu }}$

\section{REFERENCES}

1. Beard, D. F. (1998). The status of internships/cooperative education experiences in accounting education. Journal of Accounting Education, 16(3/4), 507-516. 
2. Beck, J. E. \& Halim, H. (2008). Undergraduate internships in accounting: what and how do Singapore interns learn from experience? Accounting Education: An International Journal, 17(2), 151-172.

3. Businessweek. (2006). Special report: best places to launch a career. September 16, 2006. Retrieved January 10, 1012, from http://www.businessweek.com/magazine/toc/06_38/B40010638bplc.htm

4. English, D. M. \& Koeppen, D. R. (1993). The relationship of accounting internships and subsequent academic performance. Issues in Accounting Education, 8(2), 292-299.

5. Eyler, J. T. (1992). Comparing the impact of two internship experiences on student learning. Journal of Cooperative Education, 29, 41-52.

6. Gault, J., Redington, J., \& Schlager, T. (2000). Undergraduate business internships and career success: Are they related? Journal of Marketing Education, 22(April), 45-53.

7. Giacomino, D.E. (1990). An Empirical Study of Post-Internship Academic Performance of Public Accounting Interns. Advances in Accounting, 8, 179-188.

8. Green, B., Graybeal, P. and Madison, R. (2011). An Exploratory Study of the Effect of Professional Internships on Students' Perceptions of the Importance of Employment Traits. Journal of Education for Business, 86, 100-110.

9. Henry, N. (1979). Are internships worthwhile? Public Administrative Review, 39(3), 245-247.

10. Horowitz, E. M. (1996). Chasing the pot of gold: internships on the road to employment. Annual Meeting of the Association for Education in Journalism and Mass Communications, (August).

11. Kane, S.T., Healy, C. C., \& Henson, J. (1992). College students and their part-time jobs: job congruency, satisfaction and quality. Journal of Employment Counseling, 28, 138-144.

12. Kennedy, P. (2003). A Guide to Econometrics, 5ed., The MIT Press, Cambridge, MS.

13. Knechel, W. R. \& Snowball, D. (1987). Accounting internships and subsequent academic performance: an empirical study. The Accounting Review, (October), 799-807.

14. Koehler, R. W. (1974). The effect of internship programs on subsequent college performance. The Accounting Review, (April), 362-384.

15. Knouse, S. B. Tanner, J. T., \& Harris, E. W. (1999). The relation of college internships, college performance, and subsequent job opportunity. Journal of Employment Counseling, 36(1), 35-44.

16. Liu, Y., Xu, J., \& Weitz, B. (2011). The Role of Emotional Expression and Mentoring in Internship Learning. Academy of Management Learning \& Education, 10 (1), 94-110.

17. Maletta, M. J., Anderson, B. H., \& Angelini, J. P. (1999). Experience, instruction and knowledge acquisition: a study in taxation. Journal of Accounting Education, 17, 351-366.

18. Martin, D. \& Wilkerson, J. (2006). An examination of the impact of accounting internships on student attitudes and perceptions. The Accounting Educators' Journal, 16, 129-138.

19. Moghaddam, J. M. (2011). Perceived Effectiveness of Business Internships: Student Expectations, Experiences, and Personality Traits. International Journal of Management, 28 (4), 287-303.

20. Myring, M. Bloom, R., \& Shortridge, R. T. (2005). The effect of an accounting internship on subsequent academic performance. Journal of Accounting and Finance Research, 13 (1), 169-175.

21. Nelson, I.T., Vendrzyk, V.P., Quirin, J.J., \& Allen, R. D. (2002). No, the sky is not falling: evidence of accounting student characteristics at FSA schools, 1995-2000. Issues in Accounting Education, 17(August), 277-279.

22. Nelson, I. T., Vendrzyk, V. P. Quirin, J. J. \& Kovar, S. E. (2008). Trends in accounting students characteristics: results from a 15-year longitudinal study at FSA schools. Issues in Accounting Education, 23 (August), 373-389.

23. Pasewark, W.R., Strawser, J. R., \& Wilkerson, J. E.. (1989). An empirical examination of the effect of previous internship experience on interviewing success. Journal of Accounting Education, 7, 25-39.

24. Schmutte, J. (1986). Accounting internships: the state of the art. Journal of Accounting Education, 4 (1), 227-236.

25. Siegel, P., Rigsby, J.T. (1988). The relationship of accounting internships and subsequent professional performance. Issues in Accounting Education, 3(2), 423-432.

26. Swanson, S. \& Tomkovick, C. (2012). Marketing Internships: How Values and Search Strategies Differ Across the Student-Employer Dyad. Marketing Education Review, 22(3), 251-262.

27. Weible, R. (2010). Are universities reaping the available benefits internship programs offer? Journal of Education for Business, 85, 59-63. 


\section{APPENDIX \\ SURVEY INSTRUMENT}

\section{Demographic information}

1. Gender

Male

Female

2. Age

3. Family background- work

Check all of the categories below that apply to best describe the professions represented by your parents or family in which you were raised.

Management, Business and Financial Occupations

Science, Engineering and Computer Professionals

Healthcare Practitioner Professionals

Other Professional Occupations

Technologists and Technicians

Sales Occupations

Clerical and Related Administrative Occupations

Protective Service Occupations

Service Occupations, except Protective

Construction and Extractive Craft Occupations

Installation, Maintenance and Repair Craft Occupations

Production Operative Occupations

Transportation and Material Moving Operative Occupations

Laborers, Helpers and Material Handler Occupations

Other,

\section{Family background- ethnic}

Check all that apply.

Asian American or Pacific Islander

African American or Black

Caucasian or White

Native American or Indian

Mexican American or Hispanic

Other American Ethnic Group

Non-U.S. Citizen/ Foreign

5. Family education

What is the highest level of education for one or both parents?

Doctorate (Ph.D., Medical, etc.)

Law Degree (J.D.)

Educational Specialist

Masters

Bachelors

Associates

High School Diploma

Completed Junior High

Less than eight years 
School Background

6. $\quad$ High School grade point average

3.60- 4.00

$3.20-3.59$

$2.80-3.19$

$<2.80$

7. SAT or ACT score

1360- $1600 \square$ 30-36

1160-1350 $\square \quad 26-29$

960-1150 $\square \quad 22-25$

$<960 \square<22$

8. Overall undergraduate grade point average

$3.60-4.00$

$3.20-3.59$

$2.80-3.19$

$<2.80$

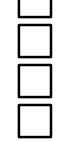

Undergra

9. Undergraduate major and grade point average. Check all that apply.

Accounting

Economics

Finance

Information Systems

Marketing

Management

Other Business

Non-Business

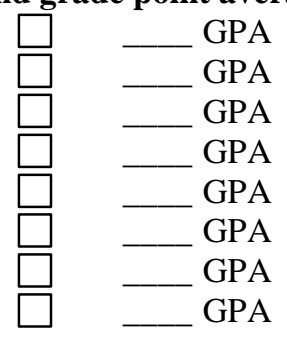

10. Masters degree

MPA

MTX

MBA

Other

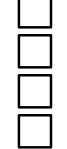

GMAT Score

600 or above

550- 590

$500-540$

$450-490$

$<450$

Not applicable

12. Overall graduate grade point average

$3.60-4.00$
$3.20-3.59$
$2.80-3.19$
$<2.80$
Not Applicable




\section{Graduate grade point average in your major or concentration}

$3.60-4.00$

$3.20-3.59$

$2.80-3.19$

$<2.80$

Not Applicable

\section{Extra Curricular Involvement- check all that apply}

Beta Alpha Psi

Beta Gamma Sigma

Accounting Society/ or Accounting Club

Other academic student organization

Other social student organization

Part-time work

\section{Employment}

15. Internships (check all that apply)

Yes, I applied for an internship in college

I had an internship during college

I did not have an internship during college

If you checked this answer, go directly to Item 20

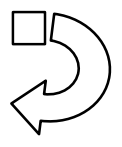

\section{Length of internships (cumulative if more than one)}

Over 12 months

7- 12 months

3- 6 months

$<3$ months

17. Internship area (check all that apply)

I had an internship in audit

I had an internship in tax

I had an internship in industry

I had an internship in another area 
18. Offer for permanent employment by internship company

I had an offer for permanent

employment

I did not have an offer for

permanent employment

19. Permanent employment by internship company

I accepted the offer

I did not accept the offer

20. Permanent employment

(including internship employer)

Number of permanent job offers prior to graduation

I accepted one of these offers

I interviewed, but did not have an

offer at graduation.

Date of first permanent job after graduation:

I planned to continue school (e.g., law)

21. My starting salary for my permanent job was:

(Note: If you have multiple degrees that were achieved several years apart, then report your starting salary after your second degree.)

$\$ 55,000$ - $\$ 60,000$

$\$ 50,000-\$ 54,999$

$\$ 45,000$ - $\$ 49,999$

$\$ 40,000-\$ 44,999$

$\$ 35,000-\$ 39,999$

$\$ 30,000-\$ 34,999$

$\$ 25,000$ - $\$ 29,999$

Below \$25,000

Not Applicable

22. I would describe my job search skills during the interview process as:

Excellent

Very good

Good

Fair

Poor

23. I would describe my leadership skills during the interview process as

Excellent

Very good

Good

Fair

Poor

24. I would describe my conversation skills during the interview process as

Excellent

Very good

Good

Fair

Poor 


\section{$\underline{\text { NOTES }}$}

